\title{
Effect of Organic Manures on Growth and Yield attributes of Beet Root Cv. Crimson Globe
}

\author{
Chitti Jagadeesh", M. Madhavi, M. Siva Prasad and V.V. Padmaja \\ Department of Vegetable Science, College of Horticulture, Dr.Y.S.R. Horticultural University, \\ Mojerla,Mahabubnagar, India \\ *Corresponding author
}

\begin{tabular}{|l|}
\hline Ke y w o r d s \\
Organic manures, \\
Specific leaf \\
weight, Crop \\
growth rate, \\
Relative growth \\
rate, Net \\
assimilation rate, \\
SPAD value, Root \\
to shoot ratio and \\
Harvest index \\
\hline Article Info \\
\hline Accepted: \\
28 October 2018 \\
Available Online: \\
10 November 2018 \\
\hline
\end{tabular}

\section{Introduction}

Beetroot (Beta vulgaris L.), also called as
garden beet or table beet, is one of the major
root vegetable belongs to the family

Beetroot (Beta vulgaris L.), also called as
garden beet or table beet, is one of the major
root vegetable belongs to the family

Beetroot (Beta vulgaris L.), also called as
garden beet or table beet, is one of the major
root vegetable belongs to the family

\section{A B S T R A C T}

A field experiment was conducted during rabi, 2014 to study the "Effect of organic manures on growth, root yield and quality of Beet root (Beta vulgaris L.)" cv. Crimson globe in alkali soils, at college farm, College of Horticulture, Dr. Y.S.R. Horticultural University, Mojerla, Mahabubnagar(Dt). The experiment was laid out in a randomized block design with three replicated 11 treatments viz., $\mathrm{T}_{1}$ : FYM (100\%), $\mathrm{T}_{2}$ : Vermicompost $(100 \%), \mathrm{T}_{3}$ : Neem cake $(100 \%), \mathrm{T}_{4}$ : Poultry manure $(100 \%), \mathrm{T}_{5}$ : Green manure $(100 \%)$, $\mathrm{T}_{6}: \mathrm{FYM}(50 \%)+$ Vermicompost $(50 \%), \mathrm{T}_{7}: \mathrm{FYM}(50 \%)+$ Neem cake $(50 \%), \mathrm{T}_{8}: \mathrm{FYM}$ $(50 \%)+$ Poultry manure (50\%), $\mathrm{T}_{9}: \mathrm{FYM}(50 \%)+$ Green manure $(50 \%), \mathrm{T}_{10}: \mathrm{RDF}, \mathrm{T}_{11}$ : Control. The data were recorded on days required for germination of seedlings, plant height $(\mathrm{cm})$, no of leaves per plant, specific leaf weight $\left(\mathrm{g} \mathrm{cm}^{-2}\right)$, crop growth rate $\left(\mathrm{g} \mathrm{m}^{-2} \mathrm{~d}^{-}\right.$ $\left.{ }^{1}\right)$, relative growth rate $\left(\mathrm{g} \mathrm{g}^{-1} \mathrm{~d}^{-1}\right)$, net assimilation rate $\left(\mathrm{g} \mathrm{cm}^{-2} \mathrm{~d}^{-1}\right)$, SPAD value, leaf area $\left(\mathrm{cm}^{-2}\right)$, root length $(\mathrm{cm})$, root diameter $(\mathrm{cm})$, root to shoot ratio, root yield per plot $(\mathrm{kg}$ plot $\left.{ }^{-1}\right)$, root yield per ha $\left(\mathrm{t} \mathrm{ha}^{-1}\right)$, harvest index $(\%)$. The early germination was recorded in poultry manure (100\%) and it was at par with FYM (50\%) + vermicompost $(50 \%)$ and vermicompost (100\%). The highest plant height and no of leaves was recorded with poultry manure $(100 \%)$ which was at par with FYM $(50 \%)+$ poultry manure $(50 \%)$. The highest specific leaf weight, crop growth rate, net assimilation rate and leaf area were recorded with poultry manure (100\%). The highest relative growth rate was recorded with vermicompost (100\%). The highest SPAD value was recorded with RDF. Among the yield parameters the root length and harvest index were maximum with FYM $(50 \%)+$ poultry manure $(50 \%)$ where as root diameter was maximum with poultry manure $(100 \%)$. The highest root yield was recorded with poultry manure (100\%) which was at par with vermicompost (100\%). The highest root: shoot ratio was recorded with FYM $(50 \%)+$ poultry manure $(50 \%)$ followed by vermicompost $(100 \%)$.
Chenopodiaceae along with spinach, palak, swiss chard, parsley, celery and it has chromosome number of $2 n=18$. Beet originated in Western Europe and North Africa where they were grown to feed both 
humans and livestock. This crop is a biennial grown as a cool season annual. It is grown in northern and southern parts of India. It is grown in almost all states of India but in small scale only. It produces green tops and a swollen root used both as vegetable and salad. It is highly productive and usually free from pests and diseases (Ado, 1999). It is a rich source of protein, carbohydrate, calcium, phosphorous and vitamin $\mathrm{C}$, hence it is an ideal vegetable for health conscious people (Deuter and Grundy, 2004). Red color of roots is due to presence of betanine pigment. It has several medicinal properties and helps in reduction of cardiovascular diseases and peripheral vascular diseases.

Organic farming is not mere non-chemical agriculture but it is a system integrating relationships between soil, plant, water, soil micro flora and fauna. Organic farming aims in creating a healthy soil, helps in proper energy flows in soil, crop, water, environment while the plant systems keeps biological life cycle alive and helps in sustaining considerable levels in yield (Lampkin, 1990).

Several attempts have been made to increase yield potential of bulb and root crops, but they are concerned with use of inorganic fertilizers which results in depletion of soil fertility and soil health. Farm yard manure being bulky organic material, releases the soil compactness and improves the aeration in addition to the supply of essential plant nutrients and organic matter and increase soil microbial establishment along with accumulation of excess humus content. It acts directly for increasing crop yield by accelerating the respiratory process through cell permeability or by hormones through growth action. It supplies nitrogen, phosphorus and sulphur in available form to the plants through biological decomposition. Indirectly it improves the physical properties of soil such as aggregation, aeration, permeability and water holding capacity (Chandramohan, 2002).

\section{Materials and Methods}

A field experiment was conducted during rabi, 2014 to study the "Effect of organic manures on growth, root yield and quality of Beet root (Beta vulgaris L.)" cv.Crimson globe in alkali soils, at college farm, College of Horticulture, Dr. Y.S.R. Horticultural University, Mojerla, Mahabubnagar(Dt). The experiment was laid out in a randomized block design with three replicated 11 treatments viz., $\mathrm{T}_{1}$ : FYM (100\%), $\mathrm{T}_{2}$ : Vermicompost (100\%), $\mathrm{T}_{3}$ : Neem cake $(100 \%), \mathrm{T}_{4}$ : Poultry manure $(100 \%), \mathrm{T}_{5}$ : Green manure $(100 \%), \mathrm{T}_{6}$ : FYM $(50 \%)+$ Vermicompost (50\%), T : FYM (50\%) + Neem cake $(50 \%), \mathrm{T}_{8}$ : FYM $(50 \%)+$ Poultry manure (50\%), $\mathrm{T}_{9}:$ FYM $(50 \%)+$ Green manure $(50 \%), \mathrm{T}_{10}$ : RDF, $\mathrm{T}_{11}$ : Control. The data were recorded on days required for germination of seedlings, plant height $(\mathrm{cm})$, no of leaves per plant, specific leaf weight $\left(\mathrm{g} \mathrm{cm}^{-}\right.$ $\left.{ }^{2}\right)$, crop growth rate $\left(\mathrm{g} \mathrm{m}^{-2} \mathrm{~d}^{-1}\right)$, relative growth rate $\left(\mathrm{g} \mathrm{g}^{-1} \mathrm{~d}^{-1}\right)$, net assimilation rate $\left(\mathrm{g} \mathrm{cm}^{-2} \mathrm{~d}^{-}\right.$ $\left.{ }^{1}\right)$, SPAD value, leaf area $\left(\mathrm{cm}^{-2}\right)$, root length $(\mathrm{cm})$, root diameter $(\mathrm{cm})$, root to shoot ratio, root yield per plot $\left(\mathrm{kg} \mathrm{plot}^{-1}\right)$, root yield per ha $\left(\mathrm{t} \mathrm{ha}^{-1}\right)$, harvest index $(\%)$.

The plant height was measured from ground level to the tip of longest leaf at 25, 50 days after sowing and at harvest from five tagged plants and their mean was worked out. Total number of leaves counted for five randomly selected plants and counted at 25, 50 days after sowing and at harvest and their mean was worked out.

The specific leaf weight on all the sampling days was calculated by using the formula

SLW $=\frac{\text { Leaf dry weight }}{---- \text { Leaf }^{2} \text { area }}$

The Crop growth rate on all the sampling days was calculated by using the formula 
$\mathrm{CGR}=\begin{array}{cc}1 & \mathrm{~W}_{2}-\mathrm{W}_{1} \\ -\mathrm{P} & \mathrm{T}_{2}-\mathrm{T}_{1}\end{array}$

Where $\mathrm{W}_{1}$ and $\mathrm{W}_{2}$ is dry weight of the whole plant at times $T_{1}$ and $T_{2}$, respectively.

Relative growth rate was calculated by using the formula

$$
\mathrm{RGR}=\frac{\log _{\mathrm{e}} \mathrm{W}_{2}-\log _{\mathrm{e}} \mathrm{W}_{1}}{\mathrm{~T}_{2}-\mathrm{T}_{1}}
$$

Where $\mathrm{W}_{1}$ and $\mathrm{W}_{2}$ represents the plant dry weights at times $T_{1}$ and $T_{2}$, respectively. The net assimilation rate was calculated by using the formula

$\mathrm{NAR}=\frac{\mathrm{W}_{2}-\mathrm{W}_{1}}{-\mathrm{T}_{2}-\mathrm{T}_{1}} \times \frac{\log _{\mathrm{e}} \mathrm{A}_{2}-\log _{\mathrm{e}} \mathrm{A}_{1}}{----}$

Where $\mathrm{W}_{1}$ and $\mathrm{W}_{2}$ are the total plant dry weights and $A_{1}$ and $A_{2}$ are leaf area at times $\mathrm{T}_{1}$ and $\mathrm{T}_{2}$, respectively.

The Spad value was calculated by using the Spad meter Leaf area of each plant was recorded with the help of a graphical method individually from the five tagged plants in each replication of all treatments at different intervals and average was worked out. It was expressed in square centimetres. The length of root from five randomly selected plants in each plot was recorded by means of scale from apex to the base of the root and the average is expressed in centimeters. The root diameter was recorded with the help of vernier calipers and the average was expressed in $\mathrm{cm}$. Root and shoot ratio was calculated for five randomly selected plants from each plot by measuring the root and shoot dry weight with the help of electronic balance. The roots of each treatmental plot were harvested separately and weighed by weighing machine and expressed in $\mathrm{kg}$ per plot. Harvesting was done manually when the roots attained maximum size, colour and full maturity. Matured roots harvested from the net plot were weighed and yield was expressed in $\mathrm{kg}$ per plot. It was multiplied with a factor to get estimated yield per hectare and expressed in tonnes per hectare. The Harvest index was calculated by using the formula

$$
\text { Harvest Index }=\frac{\text { Biological yield }}{- \text { Economical }} \times 100
$$

\section{Results and Discussion}

\section{Growth and yield parameters}

Data on various growth and yield characters of Beetroot crop as influenced by the different organic manures and their combinations are presented in Tables 1 to 11 .

\section{Days taken for germination}

Days required for $80 \%$ germination of Beet root seedlings was significantly influenced by the poultry manure $(100 \%)$ and it was at par with all the organic sources applied treatments except $\mathrm{T}_{8}$ (3.37), $\mathrm{T}_{5}$ (3.54) and $\mathrm{T}_{9}$ (3.67). The results are presented in the Table. 1

Among all the treatments $\mathrm{T}_{4}$ with poultry manure $(100 \%)$ resulted early (2.34 days) germination and it was at par (2.84 days) with combined application of FYM $(50 \%)+$ Vermi compost (50\%) and (3.00 days) Vermicompost (100\%). RDF recorded comparatively more number of days (4.00 days) than the treatments applied with organic treatments .Highest number of days taken to germination was observed in (5.00) with control plots. Onwu (2014) stated that early germination of beet root seeds in plots under poultry manure may be due to improvement in soil chemical properties such as soil $\mathrm{pH}$, total 
$\mathrm{N}$, available $\mathrm{P}$, organic matter, exchangeable cations and cation exchange capacity etc. And also of its high content of nitrogen, phosphorus and potassium may help in early germination of seedlings (Warman, 1986; Schjegel, 1992). The results are in conformity with findings of Mshelia and Degri (2014) in Amaranthus cadatus, They observed application of poultry manure about 5-10 $\mathrm{kg} / \mathrm{ha}$ resulted in high seed germination (about $83 \%)$.

\section{Plant height (cm)}

The plant height was significantly increased by the application of poultry manure $(100 \%)$ followed by FYM $(50 \%)$ + poultry manure (50\%) at different stages of plant growth. The results are presented in Table 2 .

At 25 DAS the highest plant height $(18.57 \mathrm{~cm})$ was recorded in $\mathrm{T}_{4}$ with poultry manure $(100 \%)$ and it was at par with $\mathrm{T}_{8}(18.50 \mathrm{~cm})$ with FYM (50\%) + poultry manure (50\%) and $\mathrm{T}_{6}$ (16.57) with FYM (50\%) + vermicompost (50\%) but significantly superior to all other treatments. RDF $\left(\mathrm{T}_{10}\right)$ recorded a plant height of $14.00 \mathrm{~cm}$ and the lowest was recorded in $\mathrm{T}_{11}(11.27 \mathrm{~cm})$ under control condition. At 50 DAS the highest plant height $35.70 \mathrm{~cm}$ was recorded in $\mathrm{T}_{4}$ with poultry manure $(100 \%)$ which was significantly superior to all other treatments. RDF $\left(\mathrm{T}_{10}\right)$ recorded a plant height of $24.47 \mathrm{~cm}$ and the lowest was recorded in $\mathrm{T}_{11}(20.00 \mathrm{~cm})$. At harvest the highest plant height $35.82 \mathrm{~cm}$ was recorded in $\mathrm{T}_{4}$ with poultry manure (100\%) which was significantly superior to all other treatments. $\mathrm{RDF}\left(\mathrm{T}_{10}\right)$ recorded a plant height of $26.54 \mathrm{~cm}$ and the lowest was recorded in $\mathrm{T}_{11}(24.67 \mathrm{~cm})$. The plant height of beet root was significantly affected in all stages of crop growth with the application of organic manures. Among different organic manures soil application of poultry manure $(100 \%)$ improved plant height at all the growth stages. Nitrogen being a major element has a profound effect on plant growth and development and as a constituent of proteins and also its effect on production of plant hormones in plants. The increased plant height with the application of poultry manure (100\%) may be attributed to their higher $\mathrm{N}$ content of $(1.18 \%)$. The positive effect of organic manure on plant height could be due to the contribution made by manure to fertility status of the soils as the soils were low in organic carbon content. Manure when decomposed increases both macro and micro nutrients as well as enhances the physicochemical properties of the soil. This could have led to its high vegetative growth.The results are in support with findings of Tiamiyu et al., 2012 in okra. Though the green manure contains high ' $\mathrm{N}$ ' content (1.80\%) than applied poultry manure $(1.18 \%)$ it could not record maximum plant height over poultry manure $(100 \%)$ may be because of slow release of nutrient availability. Okokoh and Bisong (2011) reported similarly that application of 10 to $15 \mathrm{t} / \mathrm{ha}$ of poultry manure resulted in increased height of amaranthus plants.

\section{Number of leaves}

Number of leaves were significantly affected by the application of organic manures their combinations at different stages of plant growth. The results are presented in Table 3 .

At 25 DAS, maximum number (11.47) of leaves per plant was observed in $\mathrm{T}_{5}$ with Green Manure (100\%) which was at par $\mathrm{T}_{4}$ (11.00) with all the other treatments except $\mathrm{T}_{3}$ (9.80) and $\mathrm{T}_{11}$ (8.34). At $50 \mathrm{DAS}$, the highest number of leaves was recorded in $\mathrm{T}_{4}$ (18.67) with poultry manure $(100 \%)$ which was at par with $\mathrm{T}_{8}$ (18.34), $\mathrm{T}_{2}$ (17.71), $\mathrm{T}_{1}$ (17.47) and $\mathrm{T}_{6}$ (17.35), indicating significantly superior to all other treatments. At harvest, $\mathrm{T}_{4}$ with poultry manure $(100 \%)$ recorded indicated highest number of leaves (21.47) which was at par with all the treatments except $T_{3}(19.10), T_{7}$ 
(19.64) and control (17.70). The treatment RDF $\left(\mathrm{T}_{10}\right)$ recorded 10.94, 16.00, and 20.94 numbers of leaves at 25 DAS, 50 DAS and harvesting stage respectively. The lowest number of leaves $(8.34,14.40$ and 17.70) was observed in control at 25 DAS, 50 DAS and harvesting stage. Among all the treatments, the number of leaves of beet root was higher with poultry manure $(100 \%)$ during progressive growth stage up to 50 DAS but at harvesting stage it was at par with all other treatments except $\mathrm{T}_{3}$ (16.76), $\mathrm{T}_{7}$ (15.80) and control $\left(\mathrm{T}_{11}\right)$.

Application of organic manures to the soil, physical condition of the soil will be improved by the better aggregation of soil particles (Samandasingh et al., 1988). These aggregates effects the soil fertility and often determine the retention and movement of water, diffusion of gases, growth and development of roots in the soil which contributed to the growth of the plant (Ghildyal and Gupta, 1991 and Arulmozhian,1996). Since, poultry manure $(100 \%)$ contains high amount of major nutrients comparative to the other organic nutrients used as treatments probably which helps for the proper growth and development of vegetative structures (i.e., leaves). The results were in conformity with findings of Tiamiyu et al., 2012 in okra. Okokoh and Bisong (2011) reported similar findings that application of 10 to $15 \mathrm{t} /$ ha of poultry manure enhanced the performance of Amaranthus in a study in Calabar, Nigeria. Mean number of leaves per plant were found to be significantly influenced by poultry manure application in amaranthus.

\section{Specific leaf weight $\left(\mathrm{mgcm}^{-2}\right)$}

The specific leaf weight recorded during the growth periods of 25 DAS, 50 DAS and harvesting stage were statistically analysed and presented in table. 4 .
The specific leaf weight was low during the early stage (25DAS) of the plant growth but it increased gradually with the advancement of age. At 25 DAS, maximum specific leaf weight (2.56) was observed in $\mathrm{T}_{4}$ with poultry manure $(100 \%)$ which was at par (2.50) with $\mathrm{T}_{8}$ - FYM $(50 \%)+$ poultry manure $(50 \%)$, (2.46) with $\mathrm{T}_{6}-\mathrm{FYM}(50 \%)+$ vermicompost (50\%), (2.40) with $\mathrm{T}_{2}$ - vermicompost (100\%), (2.39) with T9 FYM $(50 \%)$ + green manure (50\%), (2.31) with $\mathrm{T}_{5}$ - green manure $(100 \%)$ indicating significantly superior to all other treatments. At $50 \mathrm{DAS}$, the highest specific leaf weight of 7.98 was recorded in $\mathrm{T}_{4}$ with poultry manure $(100 \%)$ which was at par with $\mathrm{T}_{3}$ (7.59), $\mathrm{T}_{8}$ (7.40), $\mathrm{T}_{6}$ (7.39) and $\mathrm{T}_{5}$ (7.34) indicating significantly superior to all other treatments. At harvest, $\mathrm{T}_{4}$ with poultry manure (100\%) reported specific leaf weight of 19.09 indicating significantly superior to all other treatments. The treatment $\mathrm{RDF}\left(\mathrm{T}_{10}\right)$ recorded $2.17,4.83$, and 11.36 specific leaf weight at 25 DAS, 50 DAS and harvesting stage respectively. The lowest specific leaf weight (2.05, 4.78 and 10.21) was observed in control at 25 DAS, 50 DAS and harvesting stage.

\section{Crop growth rate $\left(\mathrm{g} \mathrm{m}^{-2} \mathrm{~d}^{-1}\right)$}

The crop growth rate recorded during the growth periods of 25-50 DAS and 50 DASharvesting were statistically analyzed and presented in table.5.

The crop growth rate was low during the early stage (25-50 DAS) of the plant growth but it increased gradually with the advancement of age of the plant. The highest crop growth rate during 25-50 DAS was recorded (0.55) in the treatment $\left(\mathrm{T}_{4}\right)$ poultry manure $(100 \%)$ closely followed by $\mathrm{T}_{2}(0.47)$ with vermicompost $(100 \%))$ and $\mathrm{T}_{7}(0.43)$ with (FYM (50\%) + neem cake $(50 \%)$, which were statistically at par. During advanced stage of crop growth at 50 DAS-harvesting, the maximum crop growth rate $(0.96)$ was recorded with $\mathrm{T}_{3}$ which 
was at par with $\mathrm{T}_{8}$ FYM $(50 \%)+$ poultry manure $(50 \%)$. In both the stages, crop growth rate enhanced with the increase in the quantity of different kinds of manures. This might be due to the availability of the required quantity of nutrients with increase in the quantity of different kinds of manures. However, the minimum crop growth rate $(0.26$ and 0.53$)$ was, recorded in control at the said stages of crop growth i. e. 25-50 DAS and 50-harvest, respectively. Increased crop growth rate during growth phase of plant is a usual phenomenon for sufficient vegetative growth necessary for successful transformation for optimum yield. The influence of organic manures on leaf number LAI, DMP, was superior over inorganic fertilizer application (Subbarao and Ravisankar, 2001). Moreover, the results are in agreement with findings of Sharu (2002) in chilli.

\section{Relative growth rate $\left(\mathrm{g} \mathrm{g}^{-1} \mathrm{~d}^{-1}\right)$}

The crop growth rate recorded during the growth periods of 25-50 DAS and 50 DASharvest were statistically analysed and presented in the table.6.

The relative growth rate was very high during the early stage (25-50 DAS) of the plant growth but it decreased gradually with the advancement of age of the plant. The highest relative growth rate (92.87) during 25-50 DAS was recorded in the treatment $\left(\mathrm{T}_{2}\right)$ with vermicompost $(100 \%)$ which was at par with $\mathrm{T}_{4}$ (92.17) with poultry manure $(100 \%), \mathrm{T}_{7}$ (86.54) with FYM $(50 \%)+$ neem cake $(50 \%)$ and $\mathrm{T}_{5}$ green manure $(100 \%)$ (86.10). In the advanced stage of crop growth at 50 DASharvest, the maximum relative growth rate (51.63) was recorded in $\mathrm{T}_{9}$ with (FYM (50\%) + Green Manure (50\%). The minimum relative growth rate (67.34 and 24.38) was recorded in control at the said stages of crop growth i.e. 25-50 DAS and 50 DAS-harvest, respectively.
Generally, RGR always decreases over as the biomass of a plant increases. The biomass of plant in control should be less, RGR should be more when compared to other treatments. This may be due to, the top leaves of a plant begin to shade the lower leaves and soil nutrients can become limiting. Overall, respiration scales with total biomass, but photosynthesis only scales with photosynthetic biomass and as a result biomass accumulates more slowly as total biomass increases. The beneficial effect of organic manures was evident in response of the plant when remarkable increase in relative growth rate with the different treatment was found in comparison with the control plots. Moreover, the results were in agreement with findings of Sharu (2002) in chilli.

\section{$\operatorname{NAR}\left(\mathrm{mg} \mathrm{cm}^{-2} \mathrm{~d}^{-1}\right)$}

The net assimilation rate recorded during the growth periods of 25-50 DAS and 50 DASharvest were statistically analyzed and presented in table. 7 .

The net assimilation rate was very high during the early stage (25 DAS-50 DAS) of the plant growth but it decreased gradually with the advancement of age of the plant. The highest net assimilation rate (8.99) during 25 DAS-50 DAS was recorded in the treatment $\left(\mathrm{T}_{4}\right)$ with poultry manure $(100 \%)$. However, it was on par with $\mathrm{T}_{2}(8.10), \mathrm{T}_{5}(7.80), \mathrm{T}_{7}$ (7.39) and $\mathrm{T}_{3}$ (7.10). In the advanced stage of crop growth at 50 DAS-harvest the maximum net assimilation rate (8.99) was recorded in $\mathrm{T}_{8}$ $($ FYM $(50 \%)+$ poultry Manure $(50 \%)$ and was par with $\mathrm{T}_{3}$ (8.38). It was due to application of neem cake, FYM, vermicompost, poultry manure and green manure may enhance the nitrogen content in the plant which leads to the increase in the chlorophyll content of leaf and ultimately increases the NAR. 


\section{SPAD value}

At 25 DAS the highest chlorophyll index (13.90) was recorded in $T_{5}$ with green manure (100\%) which was at par with all other treatments except $\mathrm{T}_{3}, \mathrm{~T}_{9}$ and $\mathrm{T}_{11}$ which are significantly lowest in SPAD value.

At 50 DAS and at harvest the highest chlorophyll index of 18.74 was recorded in $\mathrm{T}_{10}$

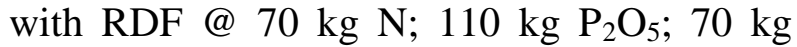
$\mathrm{K}_{2} \mathrm{O}$ and was at par with all treatments except $\mathrm{T}_{2}, \mathrm{~T}_{6}$ and $\mathrm{T}_{11}$, which were significantly lowest to all other treatments. RDF recorded chlorophyll index of 11.28, 18.74 and 15.35 at $25,50 \mathrm{DAS}$ and at harvest respectively. The lowest chlorophyll index (8.81, 13.01 and 14.34) recorded in $T_{11}$ with control at all the stages of crop growth. Nitrogen is the major constituent of chlorophyll, proteins and amino acids, the synthesis of which is accelerated by the increased supply of nitrogen in soil (Arnon, 1943; Gupta and Rao, 1979; and Verma et al., 1974). Better availability of nutrients and the balanced $\mathrm{C} / \mathrm{N}$ ratio might have increased synthesis of higher chlorophyll index in all the organic sources applied treatments except $\mathrm{T}_{2}$ with vermicompost (100\%), T 6 FYM (50\%) + vermicompost (50\%) and $\mathrm{T}_{11}$ with control (Jose et al., 1998).

\section{Leaf area $\left(\mathrm{cm}^{2}\right)$}

Leaf area was significantly affected by the application of poultry manure (100\%) at different stages of plant growth. The results are presented in Table 9.

Leaf area differed significantly between the treatments at all stages of the crop growth. The plants showed higher leaf area $(1035.46,1398.33$ and 1319.70) when the plants were applied with poultry manure (100\%) at all the stages i.e.,25, 50 DAS and harvesting stage of growth. At $25 \mathrm{DAS} \mathrm{T}_{4}$ was significantly superior to all treatments except to $\mathrm{T}_{8}$ treatments. RDF @ $70 \mathrm{~kg} \mathrm{~N} ; 110 \mathrm{~kg}$ $\mathrm{P}_{2} \mathrm{O}_{5} ; 70 \mathrm{~kg} \mathrm{~K} 2 \mathrm{O}$ resulted $384.08,761.58$ and $926.90 \mathrm{~cm}^{2}$ at 25,50 DAS and harvesting stage. The crop in $\mathrm{T}_{11}$ registered lowest leaf area $(330.12,732.13$, and 868.82, respectively) in all the growth stages. Leaf area is the best measure of the capacity of a crop for producing dry matter, which is called as its productive capital. In this experiment, availability of adequate nutrients by application of poultry manure $(100 \%)$ might have resulted better growth of the plants as observed with good plant height which ultimately found to be beneficial for high leaf area through out all growth stages. The results are similar to the findings of Bharad et al., 2013 in spinach by using FYM@ 10 t.ha $^{-1}$

\section{Root length (cm)}

The root length was significantly affected by the application of FYM, vermicompost, neem cake, poultry manure and green manure at different stages of plant growth. The results are presented in Table 10.

The highest root length of $13.35 \mathrm{~cm}$ was recorded in $\mathrm{T}_{8}$ with FYM $(50 \%)+$ poultry Manure $(50 \%)$ was at par with $\mathrm{T}_{1}(12.83 \mathrm{~cm})$ with FYM (100\%), $\mathrm{T}_{2}$ vermicompost (100\%), $\mathrm{T}_{3}, \mathrm{~T}_{4}$ and $\mathrm{T}_{9}$. RDF recorded a root length of $9.82 \mathrm{~cm}$ at harvest. The lowest root length was recorded in $\mathrm{T}_{11}(9.50 \mathrm{~cm})$ in control, which was on par with $\mathrm{T}_{10}$ (9.82), $\mathrm{T}_{5}$ (10.67), $\mathrm{T}_{6}$ (10.87) and $\mathrm{T}_{7}$ (11.07) treatments. Among all the treatments, the root length of beet root was higher with FYM (50\%) in combination with Poultry Manure (50\%).This may be due to the higher content of phosphorus $(1.35 \%)$ in poultry manure.

Phosphorus stimulates root growth, greater absorption and translocation of nutrients. It is also a part of various enzymes, co-enzymes and energy rich ATP resulting in increased root growth (Mangal, 1985). Phosphorus also 
brings about improvement in the physico chemical characteristics of the soil (Schmidt, 1954). With the application of organic manures to the soil, physical condition of the soil will be improved by the better aggregation of soil particles (Samandasingh et al., 1988). These aggregates effects the soil fertility and often determine the retention and movement of water, diffusion of gases, growth and development of roots in the soil which contributed to the growth of the plant (Ghildyal and Gupta, 1991 and Arulmozhian, 1996). In addition to this, application of organics helps the soil micro-organisms to produce polysaccharides and thus leads to better soil structure useful for root growth (Balasubramanian, 1972).

\section{Root diameter (cm)}

The root diameter was significantly affected by the application of poultry manure $(100 \%)$ and green manure $(100 \%)$ The results are presented in Table 10.

The highest root diameter (6.91) was recorded in $\mathrm{T}_{4}$ with Poultry Manure (100\%) which was at par $\mathrm{T}_{5}(6.55 \mathrm{~cm})$ with green manure (100\%), $\mathrm{T}_{3}$ (6.42), $\mathrm{T}_{1}$ (6.07), $\mathrm{T}_{2}(5.93)$ and $\mathrm{T}_{6}$ (5.95) significantly superior to all other treatments. RDF recorded a root diameter of 5.03 with RDF@ $70 \mathrm{~kg} \mathrm{~N} ; 110 \mathrm{~kg} \mathrm{P}_{2} \mathrm{O}_{5} ; 70$ $\mathrm{kg} \mathrm{K} \mathrm{K}_{2} \mathrm{O}$. The lowest was recorded in $\mathrm{T}_{11}$ (4.74) in control $\left(T_{11}\right)$. The higher root diameter recorded may be attributed to enhanced cell division and quick cell multiplication. Okokoh and Bisong (2011) reported poultry manure application had significant influence on stem diameter and the result showed that the application of 10,15 and $20 \mathrm{t} /$ ha of poultry manure resulted in sufficiently larger stem diameter than other treatments.

\section{Harvest index}

The Harvest index was significantly affected by the application of FYM $(50 \%)+$ Poultry Manure $(50 \%)$ at different stages of plant growth. The results are presented in Table 10 .

The highest harvest index $(0.85)$ was recorded in $\mathrm{T}_{8}$ with FYM $(50 \%)+$ Poultry Manure $(50 \%)$ was at par $\mathrm{T}_{2}(0.80)$ with vermicompost $(100 \%)$ and $\mathrm{T}_{4}$ with poultry manure $(100 \%)$ which were significantly superior to all other treatments.

RDF recorded harvest index 0.72 and $T_{11}$ with control resulted lowest harvest index i.e.0.70.

\section{Root yield (Kg/plot)}

The total root yield (kg/plot) was significantly affected by the application of vermicompost, poultry manure and FYM $(50 \%)+$ poultry manure $(50 \%)$ at different stages of plant growth. The results are presented in Table 11.

The highest root yield (7.52) was recorded in $\mathrm{T}_{4}$ with the application of poultry manure $(100 \%)$ which was at a par with $\mathrm{T}_{2}$ (7.03) with vermicompost (100\%) but significantly superior to all other treatments. RDF recorded an yield of $3.96 \mathrm{Kg} / \mathrm{plot}$ and the lowest was recorded in $\mathrm{T}_{11}$ (1.91).

\section{Root yield ( ha $\left.^{-1}\right)$}

The total root yield was significantly affected by the application of vermicompost, poultry manure and FYM (50\%) + poultry manure) at different stages of plant growth. The results are presented in Table 11.

The highest root yield (18.78) was recorded in $\mathrm{T}_{4}$ with the application of poultry manure (100\%) followed by $\mathrm{T}_{2}$ (17.58) with vermicompost $(100 \%)$ which were at par but significantly superior to all other treatments. RDF recorded an yield of 9.90 and the lowest was recorded in $T_{11}$ (4.77) with control $\left(T_{11}\right)$. 
Table.1 Effect of different organic manures on number of days required for $80 \%$ germination of seedlings of Beet root

\begin{tabular}{|c|c|}
\hline Treatments & DAS (Days after sowing) \\
\hline $\mathrm{T}_{1}:$ FYM $(\mathbf{1 0 0 \%})$ & 3.27 \\
\hline $\mathrm{T}_{2}:$ Vermicompost $(\mathbf{1 0 0 \%})$ & 3.00 \\
\hline $\mathrm{T}_{3}:$ Neem cake $(\mathbf{1 0 0 \%})$ & 3.17 \\
\hline $\mathrm{T}_{4}:$ Poultry Manure $(\mathbf{1 0 0 \%})$ & 2.34 \\
\hline $\mathrm{T}_{5}:$ Green Manure $(\mathbf{1 0 0 \%})$ & 3.54 \\
\hline $\mathrm{T}_{6}:$ FYM $(\mathbf{5 0 \%})+$ Vermiompost $(\mathbf{5 0 \%})$ & 2.84 \\
\hline $\mathrm{T}_{7}:$ FYM $(50 \%)+$ Neem cake $(50 \%)$ & 3.00 \\
\hline $\mathrm{T}_{8}:$ FYM $(50 \%)+$ Poultry Manure $(50 \%)$ & 3.37 \\
\hline $\mathrm{T}_{9}:$ FYM $(50 \%)$ + Green Manure $(50 \%)$ & 3.67 \\
\hline $\mathrm{T}_{10}: \mathrm{RDF} @ 70 \mathrm{~kg} \mathrm{~N} ; 110$ kg $\mathrm{P}_{2} \mathrm{O}_{5} ; 70$ kg K2O & 4.00 \\
\hline $\mathrm{T}_{11}:$ Control & 5.00 \\
\hline $\mathrm{C}$ at $5 \%$ & 1.10 \\
\hline $\mathrm{SE}(\mathrm{m}) \pm$ & 0.37 \\
\hline
\end{tabular}

Table.2 Effect of different organic manures on plant height $(\mathrm{cm})$ of Beet root at different stages of crop growth

\begin{tabular}{|c|c|c|c|}
\hline Treatments & 25 DAS & 50 DAS & At harvest \\
\hline $\mathrm{T}_{1}:$ FYM $(\mathbf{1 0 0 \%})$ & 15.84 & 26.67 & 31.87 \\
\hline $\mathrm{T}_{2}:$ Vermicompost $(\mathbf{1 0 0 \%})$ & 15.87 & 30.12 & 30.94 \\
\hline$T_{3}:$ Neem cake $(100 \%)$ & 14.70 & 27.87 & 30.14 \\
\hline $\mathrm{T}_{4}$ : Poultry Manure $(\mathbf{1 0 0 \%})$ & 18.57 & 35.70 & 35.82 \\
\hline $\mathrm{T}_{5}$ : Green Manure $(\mathbf{1 0 0 \%})$ & 16.40 & 28.60 & 28.67 \\
\hline $\begin{array}{l}\mathrm{T}_{6}: \text { FYM }(50 \%)+\text { Vermiompr } \\
(50 \%)\end{array}$ & 16.57 & 28.74 & 29.94 \\
\hline $\begin{array}{l}\mathrm{T}_{7}: \mathrm{FYM}(50 \%)+\text { Neem cake } \\
(50 \%)\end{array}$ & 15.24 & 23.04 & 23.07 \\
\hline $\begin{array}{l}T_{8}: \text { FYM }(50 \%)+\text { Poultry } \\
\text { Manure }(50 \%)\end{array}$ & 18.50 & 28.87 & 29.67 \\
\hline $\begin{array}{l}\mathrm{T}_{9}: \text { FYM }(50 \%)+\text { Green } \\
\text { Manure }(50 \%)\end{array}$ & 13.70 & 27.77 & 27.87 \\
\hline $\begin{array}{l}\mathrm{T}_{10}: \text { RDF @ } 70 \mathrm{~kg} \mathrm{~N} ; 110 \mathrm{~kg} \\
\mathrm{P}_{2} \mathrm{O}_{5} ; 70 \mathrm{~kg} \mathrm{~K} \mathrm{~K}_{2} \mathrm{O}\end{array}$ & 14.00 & 24.47 & 26.54 \\
\hline $\mathrm{T}_{11}:$ Control & 11.27 & 20.00 & 24.67 \\
\hline $\mathrm{CD}$ at $5 \%$ & 2.03 & 3.63 & 2.48 \\
\hline $\mathrm{SE}(\mathrm{m}) \pm$ & 0.69 & 1.23 & 0.84 \\
\hline
\end{tabular}


Table.3 Effect of different organic manures on number of leaves per plant of Beet root at different stages of crop growth

\begin{tabular}{|c|c|c|c|}
\hline Treatments & $25 \mathrm{DAS}$ & AS & rest \\
\hline $\mathrm{T}_{1}:$ FYM $(\mathbf{1 0 0 \%})$ & 10.40 & 17.47 & 20.40 \\
\hline $\mathrm{T}_{2}:$ Vermicompost $(\mathbf{1 0 0 \%})$ & 9.94 & 17.71 & 20.04 \\
\hline $\mathrm{T}_{3}:$ Neem cake $(\mathbf{1 0 0 \%})$ & 9.80 & 16.76 & 19.10 \\
\hline $\mathrm{T}_{4}:$ Poultry Manure $(100 \%)$ & 11.00 & 18.67 & 21.47 \\
\hline $\mathrm{T}_{5}:$ Green Manure $(\mathbf{1 0 0 \%})$ & 11.47 & 15.48 & 21.00 \\
\hline $\begin{array}{l}\mathrm{T}_{6}: \text { FYM }(50 \%)+\text { Vermicompost } \\
(50 \%)\end{array}$ & 9.87 & 17.35 & 19.80 \\
\hline $\mathrm{T}_{7}: \mathrm{FYM}(50 \%)+$ Neem cake $(50 \%$ & 9.87 & 15.80 & 19.64 \\
\hline $\begin{array}{l}\mathrm{T}_{8}: \text { FYM }(50 \%)+\text { Poultry Manure } \\
(50 \%)\end{array}$ & 9.94 & 18.34 & 19.90 \\
\hline $\begin{array}{l}\mathrm{T}_{9}: \text { FYM }(50 \%)+\text { Green Manure } \\
(50 \%)\end{array}$ & 9.94 & 16.58 & 19.74 \\
\hline $\begin{array}{l}\mathrm{T}_{10}: \text { RDF @ } 70 \text { kg N; } 110 \text { kg } P_{2} O_{5} ; ? \\
\text { kg K } \mathrm{K}_{2} \mathrm{O}\end{array}$ & 10.94 & 16.00 & 20.94 \\
\hline $\mathrm{T}_{11}:$ Control & 8.34 & 14.40 & 17.70 \\
\hline $\mathrm{CD}$ at $5 \%$ & 1.61 & 1.82 & 1.76 \\
\hline $\mathrm{SE}(\mathrm{m}) \pm$ & 0.54 & 0.62 & 0.59 \\
\hline
\end{tabular}

Table.4 Effect of different organic manures on specific leaf weight $\left(\mathrm{mg} \mathrm{cm}^{-2}\right)$ of Beet root at different stages of crop growth

\begin{tabular}{|c|c|c|c|}
\hline Treatments & 25 DAS & $50 \mathrm{DAS}$ & At harvest \\
\hline $\mathrm{T}_{1}: \mathbf{F Y M}(\mathbf{1 0 0 \%})$ & 2.07 & 5.23 & 9.40 \\
\hline $\mathrm{T}_{2}:$ Vermicompost $(\mathbf{1 0 0 \%})$ & 2.40 & 5.55 & 10.87 \\
\hline$T_{3}:$ Neem cake $(100 \%)$ & 2.15 & 7.59 & 14.18 \\
\hline $\mathrm{T}_{4}$ : Poultry Manure $(100 \%)$ & 2.56 & 7.98 & 19.09 \\
\hline $\mathrm{T}_{5}:$ Green Manure (100\%) & 2.31 & 7.34 & 10.52 \\
\hline $\mathrm{T}_{6}:$ FYM $(50 \%)+$ Vermiompost $(50 \%)$ & 2.46 & 7.39 & 10.96 \\
\hline $\mathrm{T}_{7}:$ FYM $(50 \%)+$ Neem cake $(50 \%)$ & 2.26 & 6.01 & 10.59 \\
\hline $\begin{array}{l}\mathrm{T}_{8}: \text { FYM }(50 \%)+\text { Poultry Manure } \\
(50 \%)\end{array}$ & 2.50 & 7.40 & 14.62 \\
\hline $\mathrm{T}_{9}:$ FYM $(50 \%)+$ Green Manure $(50 \%$ & 2.39 & 5.05 & 12.84 \\
\hline $\begin{array}{l}\mathrm{T}_{10}: \text { RDF @ } 70 \mathrm{~kg} \mathrm{~N} ; 110 \mathrm{~kg} \mathrm{P}_{2} \mathrm{O}_{5} ; 70 \mathrm{k} \\
\mathrm{K}_{2} \mathrm{O}\end{array}$ & 2.17 & 4.83 & 11.36 \\
\hline $\mathrm{T}_{11}:$ Control & 2.05 & 4.78 & 10.21 \\
\hline $\mathrm{CD}$ at $5 \%$ & 0.26 & 1.29 & 3.79 \\
\hline $\mathrm{SE}(\mathrm{m}) \pm$ & 0.09 & 0.44 & 1.28 \\
\hline
\end{tabular}


Table.5 Effect of different organic manures on crop growth rate $\left(\mathrm{gm}^{-2} \mathrm{~d}^{-1}\right)$ of Beet root at different stages of crop growth

\begin{tabular}{|c|c|c|}
\hline Treatments & 25-50 DAS & 50- At harvest DAS \\
\hline $\mathrm{T}_{1}: \mathbf{F Y M}(\mathbf{1 0 0 \%})$ & 0.29 & 0.60 \\
\hline $\mathrm{T}_{2}:$ Vermicompost $(\mathbf{1 0 0 \%})$ & 0.47 & 0.72 \\
\hline $\mathrm{T}_{3}:$ Neem cake $(\mathbf{1 0 0 \%})$ & 0.36 & 0.96 \\
\hline $\mathrm{T}_{4}$ : Poultry Manure $(\mathbf{1 0 0 \%})$ & 0.55 & 0.64 \\
\hline $\mathrm{T}_{5}:$ Green Manure (100\%) & 0.39 & 0.54 \\
\hline $\mathrm{T}_{6}:$ FYM $(50 \%)+$ Vermiocmpost $(50 \%)$ & 0.35 & 0.60 \\
\hline $\mathrm{T}_{7}:$ FYM $(50 \%)+$ Neem cake $(50 \%)$ & 0.43 & 0.56 \\
\hline $\mathrm{T}_{8}:$ FYM $(50 \%)+$ Poultry Manure $(50 \%)$ & 0.37 & 0.82 \\
\hline $\mathrm{T}_{9}:$ FYM $(50 \%)+$ Green Manure $(50 \%)$ & 0.27 & 0.58 \\
\hline $\mathrm{T}_{10}:$ RDF @ 70 kg N; 110 kg $\mathrm{P}_{2} \mathrm{O}_{5} ; 70$ kg K2O & 0.26 & 0.54 \\
\hline $\mathrm{T}_{11}:$ Control & 0.26 & 0.53 \\
\hline $\mathrm{CD}$ at $5 \%$ & 0.12 & 0.19 \\
\hline $\mathrm{SE}(\mathrm{m}) \pm$ & 0.04 & 0.07 \\
\hline
\end{tabular}

Table.6 Effect of different organic manures on relative growth rate $\left(\mathrm{mg} \mathrm{g}^{-1} \mathrm{~d}^{-1}\right)$ of Beet root at different stages of crop growth

\begin{tabular}{|c|c|c|}
\hline $\mathrm{T}_{1}: \mathbf{F Y M}(\mathbf{1 0 0 \%})$ & 25-50 DAS & 50- At harvest DAS \\
\hline $\mathrm{T}_{2}:$ Vermicompost $(\mathbf{1 0 0 \%})$ & 60.27 & 36.36 \\
\hline $\mathrm{T}_{3}:$ Neem cake $(\mathbf{1 0 0 \%})$ & 92.87 & 34.52 \\
\hline $\mathrm{T}_{4}:$ Poultry Manure $(\mathbf{1 0 0 \%})$ & 72.97 & 46.07 \\
\hline $\mathrm{T}_{5}$ : Green Manure (100\%) & 92.17 & 28.92 \\
\hline $\mathrm{T}_{6}:$ FYM $(50 \%)+$ Vermicompost $(50 \%)$ & 86.10 & 27.75 \\
\hline $\mathrm{T}_{7}:$ FYM $(50 \%)+$ Neem cake $(50 \%)$ & 77.34 & 40.18 \\
\hline $\mathrm{T}_{8}:$ FYM $(50 \%)+$ Poultry Manure $(50 \%)$ & 86.54 & 26.17 \\
\hline $\mathrm{T}_{9}:$ FYM $(50 \%)$ + Green Manure $(50 \%)$ & 66.04 & 44.01 \\
\hline $\begin{array}{l}\mathrm{T}_{10}: \text { RDF @ } 70 \text { kg N; } 110 \text { kg } \mathbf{P}_{2} \mathrm{O}_{5} ; 70 \mathrm{~kg} \\
\mathrm{~K}_{2} \mathrm{O}\end{array}$ & 63.50 & 51.63 \\
\hline $\mathrm{T}_{11}:$ Control & 82.37 & 41.57 \\
\hline $\mathrm{CD}$ at $5 \%$ & 67.34 & 24.38 \\
\hline \multirow[t]{2}{*}{$\mathrm{SE}(\mathrm{m}) \pm$} & 18.20 & 10.32 \\
\hline & 6.13 & 3.48 \\
\hline
\end{tabular}


Table.7 Effect of different organic manures on net assimilation rate $\left(\mathrm{mg} \mathrm{cm}^{-2} \mathrm{~d}^{-1}\right)$ of Beet root at different stages of crop growth

\begin{tabular}{|c|c|c|}
\hline Treatments & 25-50 DAS & 50- At harvest DAS \\
\hline $\mathrm{T}_{1}:$ FYM $(\mathbf{1 0 0 \%})$ & 5.14 & 5.09 \\
\hline $\mathrm{T}_{2}:$ Vermicompost $(\mathbf{1 0 0 \%})$ & 8.10 & 7.27 \\
\hline $\mathrm{T}_{3}:$ Neem cake $(100 \%)$ & 7.10 & 8.38 \\
\hline $\mathrm{T}_{4}:$ Poultry Manure $(\mathbf{1 0 0 \%})$ & 8.99 & 6.18 \\
\hline $\mathrm{T}_{5}:$ Green Manure (100\%) & 7.80 & 4.54 \\
\hline $\begin{array}{l}\mathrm{T}_{6}: \text { FYM }(50 \%)+\text { Vermicompost } \\
(50 \%)\end{array}$ & 5.95 & 6.19 \\
\hline $\mathrm{T}_{7}:$ FYM $(50 \%)+$ Neem cake $(50 \%)$ & 7.39 & 3.98 \\
\hline $\begin{array}{l}\mathrm{T}_{8}: \text { FYM }(50 \%)+\text { Poultry Manure } \\
(\mathbf{5 0 \%})\end{array}$ & 6.41 & 8.99 \\
\hline $\begin{array}{l}\mathrm{T}_{9}: \text { FYM }(50 \%)+\text { Green Manure } \\
(50 \%)\end{array}$ & 4.65 & 5.45 \\
\hline $\begin{array}{l}\mathrm{T}_{10}: \text { RDF @ } 70 \mathrm{~kg} \mathrm{~N} ; 110 \mathrm{~kg} \mathrm{P}_{2} \mathrm{O}_{5} \\
70 \mathrm{~kg} \mathrm{~K} \mathrm{~K}_{2} \mathrm{O}\end{array}$ & 5.61 & 4.41 \\
\hline $\mathrm{T}_{11}:$ Control & 4.62 & 4.23 \\
\hline $\mathrm{CD}$ at $5 \%$ & 1.90 & 1.56 \\
\hline $\mathrm{SE}(\mathrm{m}) \pm$ & 0.64 & 0.53 \\
\hline
\end{tabular}

Table.8 Effect of different organic manures on SPAD Value of Beet root at different stages of crop growth

\begin{tabular}{|c|c|c|c|}
\hline Treatments & $25 \mathrm{DAS}$ & $50 \mathrm{DAS}$ & At harvest \\
\hline $\mathrm{T}_{1}:$ FYM $(\mathbf{1 0 0 \%})$ & 12.14 & 16.55 & 17.86 \\
\hline $\mathrm{T}_{2}:$ Vermicompost $(\mathbf{1 0 0 \%})$ & 12.89 & 14.50 & 20.23 \\
\hline $\mathrm{T}_{3}:$ Neem cake $(\mathbf{1 0 0 \%})$ & 10.26 & 18.58 & 19.01 \\
\hline $\mathrm{T}_{4}:$ Poultry Manure $(\mathbf{1 0 0 \%})$ & 13.05 & 17.03 & 19.36 \\
\hline $\mathrm{T}_{5}:$ Green Manure $(\mathbf{1 0 0 \%})$ & 13.90 & 18.11 & 22.06 \\
\hline $\mathrm{T}_{6}:$ FYM $(50 \%)+$ Vermicompost $(50 \%)$ & 11.74 & 14.12 & 22.47 \\
\hline $\mathrm{T}_{7}:$ FYM $(50 \%)+$ Neem cake $(50 \%)$ & 12.46 & 15.18 & 19.48 \\
\hline $\begin{array}{l}\mathrm{T}_{8}: \text { FYM }(\mathbf{5 0 \%})+\text { Poultry Manure } \\
(\mathbf{5 0 \%})\end{array}$ & 11.56 & 16.86 & 21.26 \\
\hline $\mathrm{T}_{9}:$ FYM $(50 \%)+$ Green Manure $(50 \%)$ & 9.89 & 17.53 & 21.25 \\
\hline $\begin{array}{l}\mathrm{T}_{10}: \text { RDF @ } 70 \mathrm{~kg} \mathrm{~N} ; 110 \mathrm{~kg} \mathbf{P}_{2} \mathrm{O}_{5} ; 70 \mathrm{~kg} \\
\mathrm{~K}_{2} \mathrm{O}\end{array}$ & 11.28 & 18.74 & 15.35 \\
\hline $\mathrm{T}_{11}:$ Control & 8.81 & 13.01 & 14.34 \\
\hline $\mathrm{CD}$ at $5 \%$ & 2.73 & 3.60 & 4.51 \\
\hline $\mathrm{SE}(\mathrm{m}) \pm$ & 0.92 & 1.22 & 1.52 \\
\hline
\end{tabular}


Table.9 Effect of different organic manures on leaf area $\left(\mathrm{cm}^{2}\right)$ of Beet root at different stages of crop growth

\begin{tabular}{|c|c|c|c|}
\hline Treatments & 25 DAS & 50 DAS & At harvest \\
\hline $\mathrm{T}_{1}:$ FYM $(\mathbf{1 0 0 \%})$ & 650.46 & 978.912 & 1203.54 \\
\hline $\mathrm{T}_{2}:$ Vermicompost $(\mathbf{1 0 0 \%})$ & 580.96 & 918.08 & 1157.88 \\
\hline $\mathrm{T}_{3}:$ Neem cake $(100 \%)$ & 559.28 & 1103.05 & 1118.21 \\
\hline $\mathrm{T}_{4}$ : Poultry Manure $(100 \%)$ & 1035.46 & 1398.33 & 1319.97 \\
\hline $\mathrm{T}_{5}$ : Green Manure (100\%) & 704.48 & 1009.53 & 960.78 \\
\hline $\mathrm{T}_{6}:$ FYM $(\mathbf{5 0 \%})+$ Vermicompost $(\mathbf{5 0 \%})$ & 685.15 & 865.75 & 986.11 \\
\hline $\mathrm{T}_{7}:$ FYM $(50 \%)+$ Neem cake $(50 \%)$ & 710.85 & 801.68 & 885.70 \\
\hline $\mathrm{T}_{8}:$ FYM $(50 \%)+$ Poultry Manure $(50 \%)$ & 922.48 & 973.04 & 1182.19 \\
\hline $\mathrm{T}_{9}:$ FYM $(50 \%)+$ Green Manure $(50 \%)$ & 363.60 & 1059.59 & 1044.02 \\
\hline 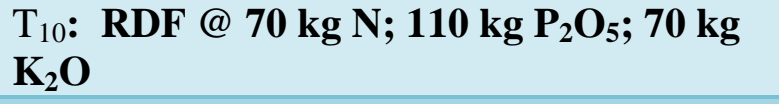 & 384.08 & 761.52 & 926.91 \\
\hline $\mathrm{T}_{11}:$ Control & 330.13 & 732.14 & 868.83 \\
\hline $\mathrm{CD}$ at $5 \%$ & 176.36 & 233.58 & 246.88 \\
\hline $\mathrm{SE}(\mathrm{m}) \pm$ & 59.37 & 78.63 & 83.11 \\
\hline
\end{tabular}

Table.10 Effect of different organic manures on root length $(\mathrm{cm})$, root diameter $(\mathrm{cm})$, harvest index of Beet root at harvest of crop growth

\begin{tabular}{|c|c|c|c|}
\hline Treatments & Root length & Root diameter & Harvest Index \\
\hline $\mathrm{T}_{1}: \operatorname{FYM}(100 \%)$ & 12.83 & 6.07 & 0.72 \\
\hline $\mathrm{T}_{2}:$ Vermicompost $(\mathbf{1 0 0 \%})$ & 12.34 & 5.93 & 0.80 \\
\hline$T_{3}:$ Neem cake $(100 \%)$ & 11.95 & 6.42 & 0.75 \\
\hline $\mathrm{T}_{4}$ : Poultry Manure $(\mathbf{1 0 0 \% )}$ & 11.87 & 6.91 & 0.79 \\
\hline $\mathrm{T}_{5}$ : Green Manure $(\mathbf{1 0 0 \% )}$ & 10.67 & 6.55 & 0.73 \\
\hline $\mathrm{T}_{6}:$ FYM $(\mathbf{5 0 \%})+$ Vermicompost & 10.87 & 5.95 & 0.76 \\
\hline $\mathrm{T}_{7}:$ FYM $(50 \%)+$ Neem cake $(50 \%)$ & 11.07 & 5.42 & 0.78 \\
\hline $\mathrm{T}_{8}:$ FYM $(50 \%)$ + Poultry Manure & 13.35 & 6.24 & 0.85 \\
\hline $\mathrm{T}_{9}:$ FYM $(50 \%)+$ Green Manure & 11.87 & 6.07 & 0.74 \\
\hline $\begin{array}{l}\mathrm{T}_{10}: \text { RDF @ } 70 \mathrm{~kg} \mathrm{~N} ; 110 \mathrm{~kg} \mathrm{P}_{2} \mathrm{O}_{5} ; 70 \\
\text { kg K} \mathrm{K}_{2} \mathrm{O}\end{array}$ & 9.82 & 5.03 & 0.72 \\
\hline $\mathrm{T}_{11}:$ Control & 9.50 & 4.74 & 0.70 \\
\hline $\mathrm{CD}$ at $5 \%$ & 2.07 & 1.08 & 0.07 \\
\hline $\mathrm{SE}(\mathrm{m}) \pm$ & 0.70 & 0.37 & 0.03 \\
\hline
\end{tabular}


Table.11 Effect of different organic manures on root yield $\left(\mathrm{kg} \mathrm{plot}^{-1}\right)$, root yield $\left(\mathrm{t} \mathrm{ha}^{-1}\right)$ and root -shoot ratio of Beet root at Harvest

\begin{tabular}{|c|c|c|c|}
\hline Treatments & Root Yield & Root Yield & Root-Shoot \\
\hline $\mathrm{T}_{1}:$ FYM $(100 \%)$ & 5.01 & 12.44 & 2.54 \\
\hline $\mathrm{T}_{2}:$ Vermicompost $(\mathbf{1 0 0 \% )}$ & 7.03 & 17.58 & 3.88 \\
\hline $\mathrm{T}_{3}:$ Neem cake $(100 \%)$ & 5.20 & 12.99 & 2.96 \\
\hline $\mathrm{T}_{4}:$ Poultry Manure $(\mathbf{1 0 0 \%})$ & 7.52 & 18.78 & 3.57 \\
\hline $\mathrm{T}_{5}$ : Green Manure $(\mathbf{1 0 0 \%})$ & 5.20 & 12.10 & 2.64 \\
\hline $\mathrm{T}_{6}:$ FYM $(\mathbf{5 0} \%)+$ Vermicompost $(\mathbf{5 0 \%})$ & 4.31 & 10.76 & 3.02 \\
\hline $\mathrm{T}_{7}:$ FYM $(50 \%)+$ Neem cake $(50 \%)$ & 4.35 & 10.87 & 3.33 \\
\hline $\mathrm{T}_{8}:$ FYM $(50 \%)+$ Poultry Manure $(50 \%)$ & 6.61 & 16.52 & 5.36 \\
\hline $\mathrm{T}_{9}:$ FYM $(\mathbf{5 0 \%})+$ Green Manure (50\%) & 4.22 & 10.55 & 2.91 \\
\hline $\mathrm{T}_{10}: \mathrm{RDF} @ 70 \mathrm{~kg} \mathrm{~N} ; 110 \mathrm{~kg} \mathrm{P}_{2} \mathrm{O}_{5} ; 70 \mathrm{~kg}$ & 3.96 & 9.90 & 2.22 \\
\hline $\mathrm{T}_{11}:$ Control & 1.91 & 4.77 & 2.09 \\
\hline $\mathrm{CD}$ at $5 \%$ & 1.72 & 4.27 & 0.99 \\
\hline $\mathrm{SE}(\mathrm{m}) \pm$ & 0.57 & 1.44 & 0.34 \\
\hline
\end{tabular}

In conclusion, all the growth and yield parameters of beet root were significantly influenced by the organic manures such as FYM, vermicompost, poultry manure, neem cake and green manure. Among all the treatments, $\mathrm{T}_{4}$ with poultry manure $(100 \%)$ resulted in early (2.34 days) germination and it was at par (2.83days) with combined application of FYM (50\%)+Vermi compost $(50 \%)$ and (3.00 days) Vermicompost $(100 \%)$. Among different organic manures, soil application of poultry manure (100\%) improved plant height at all the growth stages each recorded the highest plant height of $18.57,35.70$, and $35.82 \mathrm{~cm}$ at 25,50 , and at harvest DAS respectively. Maximum number of leaves (11.47, 18.67, and 21.47) was recorded with the application of poultry manure $(100 \%)$ each at 25,50 , and harvest DAS respectively. Among different organic manures, the specific leaf weight was recorded low during early stage (25 DAS) of the crop growth, Maximum specific leaf weight (7.98) was recorded with poultry manure (100\%) which was at par (7.59) with neem cake (100\%) at 50 DAS and at harvest the maximum specific leaf weight (19.09) was recorded with poultry manure $(100 \%)$ which was at par (14.62) with FYM (50\% + poultry manure (50\%). Among different organic manures, the highest crop growth rate during 20-50 DAS was recorded (0.55) in poultry manure $(100 \%)$ which was at par (0.47) with vermicompost $(100 \%)$ and (0.43) with FYM $(50 \%)+$ neem cake $(50 \%)$. At 50 DAS harvest the maximum crop growth rate (0.96) was recorded with neem cake (100\%) which was at par with FYM $(50 \%$ + poultry manure $(50 \%)$. Among different organic manures, the highest relative growth rate during 20-50 DAS was recorded (92.87) in vermicompost $(100 \%)$ which was at par (92.17) with poultry 
manure (100\%), (86.54) with FYM (50\%) + neem cake $(50 \%)$ and (86.10) with green manure $(100 \%)$. At 50 DAS - harvest, the maximum relative growth rate (51.63) was recorded with FYM $(50 \%)+$ green manure (50\%). Among different organic manures, the highest net assimilation rate during 20-50 DAS was recorded (8.99) in poultry manure (100\%). At 50 DAS - harvest the maximum net assimilation rate (8.99) was recorded with neem cake $(100 \%)$ and (8.38) FYM (50\%) + poultry manure $(50 \%)$. Among different organic manures, the highest chlorophyll content (13.90) was recorded in $\mathrm{T}_{5}$ with green manure $(100 \%)$ which was at par with all other treatments except $\mathrm{T}_{3}, \mathrm{~T}_{9}$ and $\mathrm{T}_{11}$. At 50 DAS and at harvest the highest chlorophyll content of 18.74 was recorded in RDF and was at par with all treatments except $T_{2}, T_{6}$ and $\mathrm{T}_{11}$. Among different organic manures, soil application of poultry manure (100\%) improved leaf area at all the growth stages each recorded the highest leaf area of $1035.46,1398.33$, and 1319.97 at 25, 50, and at harvest DAS respectively. At harvest highest root length of $13.35 \mathrm{~cm}$ respectively was recorded with the application of FYM $(50 \%)+$ poultry manure $(50 \%)$ was at par 12.82 with FYM (100\%). Maximum root diameter $(6.91 \mathrm{~cm})$ was recorded with poultry manure $(100 \%)$ at harvest which was at par with green manure $(100 \%)$, neem cake (100\%), FYM (100\%), vermi compost $(100 \%)$ and FYM $(50 \%)+$ vermicomopost $(50 \%)$. The highest total root yield (18.78 t $\mathrm{ha}^{-1}$ ) was recorded with the application of poultry manure $(100 \%)$ which was at par with vermicompost $(100 \%)$ (17.58 $\left.\mathrm{t} \mathrm{ha}^{-1}\right)$. Higher root to shoot ratio (5.36) was recorded with the application of FYM $(50 \%)+$ poultry manure $(50 \%)$ followed by vermicompost (100\%) (3.88). Higher harvest index (0.85) was recorded with the application of FYM $(50 \%)+$ poultry manure $(50 \%)$ was at par vermicompost $(100 \%)$ and poultry manure (100\%) (0.80).

\section{References}

Ado, P.O., 1999. Beetroot Cultivation. Beetroot and Eggplant Newsletter, 18: $21-24$.

Arnon, 1943. Effect of nitrogen and phosphorus on growth and seed yield of okra. Indian Journal of Horticulture. 55(3). 158-161.

Arulmozhiyan, R, Wilfredmanuel, $\mathrm{W}$ and Velmurugan, S. 2002. Effect of organics vs inorganics on betelvine cv. Vellaikodi in open system cultivation. South Indian Horticulture. 50(1-3): 169-172.

Balasubramanian, A. 1972. Effect of organic manuring on activities of enzymes hydrolyzing sources of sucrose and urea in soil aggregation. Plant and Soil. 37: 319-328.

Chandramohan, S. 2002. Organic farming in cotton + black gram intercropping system. M.Sc. (Agri.) Thesis, Tamil Nadu Agricultural University, Coimbatore

Deuter, P. and Grundy, T. (2004). Beetroot Commercial Production and Processing. Agency for Food and Fibre Sciences. Holland Horticultural Limited Partnership. P. 1 - 4.

Ghildyal, B.P and Gupta. 1991. Soil structure problems and management. Indian Council of Agricultural Research.

Jose, D, Shanmugavelu, K.G and Thamburaj, S. 1988. Studies on the efficiency of organic vs inorganic form of nitrogen in brinjal. Indian Journal of Horticulture. 45: $100-103$

Lampkin, N.1990. In: Organic farming, Ipswich, W.K., Farming Press Book, pp. 801-910.

Mshelia, J. S., Degri, M. M. 2013. Effect of different levels of poultry manure on the performance of amaranthus (amaranthus caudatus l.) in bama, nigeria 
Okokoh, S. J. and Bisong, B. W. (2011) Effect of Poultry Manure and Urea- N on Flowering Occurrence and Leaf Productivity of Amranthus cruentus in Calabar. Journ.of Apl. Sic. Environmental Management. 15. (1) 1315.

Schmidt, L. 1954. Soils Fertil, Harpenden. 18,310 .

Samandasingh, Virendrakumar and Singh, Y. 1988. Organic manures the only curve for better crop and soil health. Farmer and Parliament. 23-29-30.

Sharu, S.R. 2002. Integrated nutrient management in Chilli (Capsicum annuum L.). M.Sc.(Ag.) thesis, Kerala Agricultural University, Thrissur, p.108

Subbarao, T.S.S. and Ravisankar, C. 2001. Effect of organic manures on growth and yield of brinjal. National seminar on changing scenario in the production system of horticultural crops. Aug 2830, 2001. South Indian Horticulture, Coimbatore. pp. 288-289

Tiamiyu et al., 2012. Effect of Sources of Organic Manure on Growth and Yields of Okra (Abelmoschus esculentus L.) Agriculture Usmanu Danfodiyo University, Sokoto, Nigeria.

Verma, J.P, Rathore, S.V.S and Kushwala, C.S. 1974. Effect of level and method of application of $\mathrm{N}$ through urea on the performance of okra. Progressive Horticulture. 5(4): 77-80.

Warman PR (1986). The effect of fertilizer, chicken manure and dairy manure on Timothy yield, tissue composition and soil fertility. Agric. Wastes 18: 289-298.

\section{How to cite this article:}

Chitti Jagadeesh, M. Madhavi, M. Siva Prasad and Padmaja, V.V. 2018. Effect of Organic Manures on Growth and Yield attributes of Beet Root Cv. Crimson Globe. Int.J.Curr.Microbiol.App.Sci. 7(11): 3538-3553. doi: https://doi.org/10.20546/ijcmas.2018.711.403 